\title{
RHODOCOCCUS EQUI INFECTIONS OF PERSONS WITH AND WITHOUT A CONTACT WITH ANIMALS
}

\author{
M. VOTAVA, B. SKALKA \\ Department of Microbiology, Masaryk University Medical \\ School, St. Anna Hospital, Brno
}

Received July 23, 1996

Accepted September 24, 1996

\begin{abstract}
$\mathrm{V}$ o $\mathrm{t}$ a v a M., B. S k a $1 \mathrm{k}$ a: Rhodococcus equi Infections of Persons With and Without a Contact With Animals. Acta vet. Brno 1996, 65: 219-224.

The analysis of 115 reports on $R$. equi infection in man showed that only $59(51 \%)$ contained data on the possible exposure to animals, manure or soil. The positive contact was reported in 35 cases $(30 \%)$ and denied in 24 cases $(21 \%)$. The most common type of contact was the exposure to horses or horse manure, being mentioned in 18 cases. The next most frequent type of exposure was farming. In the animal exposure positive group the median age was 30 years, male to female ratio $(M: F)$ was 3.38 and the clinical outcome was fatal in 10 cases out of 35 (29 $\%)$. In the group of patient without the animal exposure the median age was 39 years, M:F was 3.0 and the outcome was fatal in 11 cases out of $24(46 \%)$. The differences were not significant. There was also no difference in the presence of HIV infection between patients with and without the animal exposure, HIV infection being reported in 16 out of 35 patients with the positive animal exposure and in 12 out of 24 of patients without such exposure. It is concluded that with a better epidemiological history the true percentage of $R$. equi infected persons with positive animal exposure may be higher.
\end{abstract}

Rhodococcus equi, infections of man, contact with animals, manure or soil

Rhodococcus equi (Magnusson) Goodfellow and Alderson 1977, formerly named Corynebacterium equi, has been for a long time considered a zoopathogenic microbe, mainly an agent of pneumonia in young equidae, mostly in foals (Prescott 1991). Since 1967 , infections in humans, usually pneumonias or lung abscesses, have been reported (Golub et al. 1967). Immunodeficient persons, e.g. patients under cytotoxic therapy for malignancies, under immunosuppression after renal transplantation or alcoholics, are usually infected. After acquired immunodeficiency syndrome (AIDS) turned out, many cases of rhodococcal lung infections in human immunodeficiency virus (HIV) positive persons have been reported, the first one by Samies et al. (1986).

Though many reviews of human $R$. equi infections exist (the most recent e.g. McNeil and Brown 1994; Verville et al. 1994; Scott et al. 1995), none was aimed specifically at a possible contact of patients with animals. An analytical study from this point of view was made the topic of our paper.

\section{Materials and Methods}

MEDLINE data base was searched through using the terms ,Rhodococcus equi “ and „Corynebacterium equi “ for relevant reports and references quoted in the reports were compared with our own collection of reprints. When the original source was not obtained, the data from reviews were employed (Doig et al. 1991; Drancourt et al. 1992; Harvey and Sunstrum 1991; Verville et al. 1995). Only reports concerning fully identified $R$. equi strains were considered.

We searched the text for data relative to the patient's contact with animals, esp. livestock, and with manure or soil. When the contact was not stated explicitly in the history of an individual case reported but its importance as a risk factor was mentioned by the author, such a report was considered for the purpose of this study as denying the contact of the respective patient. 


\section{Results}

Out of the 115 reports of $R$. equi infection in man described till this time, only $59(51 \%)$ contained data on the possible exposure to animals, manure or soil. Fifty nine reports with such exposure. either positive or negative, were analysed in the present study. The positive contact was reported in 35 cases $(30 \%)$ and denied in 24 cases $(21 \%)$. The most common type of contact was the exposure to horses or horse manure, being mentioned in 18 cases. Farming or working on farm was reported in 5 cases, cleaning cattle stalls in 2 cases. Once a contact with sheep was reported, once with a dog only and three times an exposure to livestock or farm animals was noted. Unspecified rural exposure or living in farm was mentioned in 3 cases. Few times the exposure was only tacit one, e.g. study of a school of agriculture (Egawa et al. 1990), being a strict vegetarian (Walsh and Cunha 1994) or frequent walking barefoot when travelling through India (A ntin ori et al. 1992), the last in a patient with a lesion on the sole of her foot. Detailed description of the possible animal contact together with age, sex, HIV infection status and clinical outcome data of patients are given in the Table 1.

Table 1

$R$. equi infections in humans having positive contact with animals, manure or soil

\begin{tabular}{|c|c|c|c|c|c|}
\hline No Age & Sex & HIV & $\begin{array}{l}\text { Out- } \\
\text { come }\end{array}$ & Description of the contact & (References) \\
\hline 1. 29 & M & - & $\mathrm{R}$ & \multicolumn{2}{|c|}{$\begin{array}{l}\text { Worked in the stockyards...cleaned out pens that had housed cattle, sheep. and } \\
\text { suine } \\
\text { (Golub et al. 1967) }\end{array}$} \\
\hline 2. 1 & M & - & $\mathrm{R}$ & \multicolumn{2}{|c|}{$\begin{array}{l}\text { Living in farm, sucking on carrots from a garden with soil contaminated by the } \\
\text { organism } \\
\text { (Verville et al., 1994) }\end{array}$} \\
\hline 3. 39 & M & - & $\mathrm{D}$ & \multicolumn{2}{|c|}{$\begin{array}{l}\text { Owned four horses and at a country fair was exposed to a large number of } \\
\text { animals } \\
\text { (Marsh \& von Graevenitz 1973) }\end{array}$} \\
\hline 4. 26 & M & - & $\mathrm{R}$ & Exposure to farm animals & (Doig et al. 1991) \\
\hline 5. 47 & $\mathrm{~F}$ & - & $\mathrm{R}$ & \multicolumn{2}{|c|}{$\begin{array}{l}\text { Lived next to a field where horses had grazed... was fond of outdoor gardening } \\
\text { and used dried cow`s manure as a fertilizer }\end{array}$} \\
\hline & & & & & (Berg et al. 1977) \\
\hline 6. 45 & $\mathrm{~F}$ & - & $\mathrm{D}$ & Farmer & (Doig et al. 1991) \\
\hline 7. 30 & M & - & $\mathrm{R}$ & Milked dairy cattle and cleaned their stalls & (van Etta et al. 1983) \\
\hline 8. 69 & M & - & $\mathrm{R}$ & Cared for livestock and domestic animals & (MacGregor et al. 1986) \\
\hline 9. & M & + & $\mathrm{R}$ & Worked as an animal and horse handler & (Wang et al. 1986) \\
\hline 10. 51 & $\mathrm{~F}$ & - & $\mathrm{R}$ & Farmer & (Doig et al. 1991) \\
\hline 11. 45 & M & + & $\mathrm{D}$ & Rural exposure & (Doig et al. 1991) \\
\hline 12. 29 & M & + & $\mathrm{R}$ & Ranch work & (Doig et al. 1991) \\
\hline 13. 6 & $\mathrm{~F}$ & - & $\mathrm{R}$ & \multicolumn{2}{|c|}{ Visited a sheep farm twice in the 3 months preceding her admission } \\
\hline 14. 28 & M & + & $\mathrm{R}$ & Worked in a farm & (Flepp et al. 1989) \\
\hline 15. 53 & M & - & $\mathrm{D}$ & Rural exposure - horse farm & (Doig et al.1991) \\
\hline 16. 28 & M & - & $\mathrm{R}$ & A student at a graduate school of agriculture & (Egawa et al. 1990) \\
\hline 17. 25 & M & + & $\mathrm{R}$ & Horse trainer & (Kwon \& Colby 1994) \\
\hline 18. 26 & M & + & $\mathrm{R}$ & Exposed to several horses at a country fair & (Doig et al. 1991) \\
\hline 19. 30 & M & + & $\mathrm{D}$ & Worked closely with Arabian horses & (Emmons et al. 1991) \\
\hline
\end{tabular}




\begin{tabular}{|c|c|c|c|c|c|}
\hline \multirow[t]{2}{*}{ 20. 29} & \multirow[t]{2}{*}{ M } & \multirow[t]{2}{*}{+} & \multirow[t]{2}{*}{$\mathbf{R}$} & \multicolumn{2}{|c|}{ Worked as a grocer...recalled having petted horses a month before his } \\
\hline & & & & symptoms began & (Lasky et al. 1991) \\
\hline 21. 25 & $\mathbf{M}$ & + & $\mathbf{R}$ & Grew up on a horse farm...had been exposed to livestock & (Obana et al. 1991) \\
\hline 22. 32 & M & + & $\mathbf{R}$ & Worked as a groom & (Rouquet et al. 1991) \\
\hline 23. 33 & M & + & $\mathbf{R}$ & Worked as a gardener...had only little contact with hors & $\begin{array}{l}\text { es and ponies } \\
\text { (Vestbo et al. 1991) }\end{array}$ \\
\hline 24. 25 & F & + & $\mathbf{R}$ & Travelled through India, frequently walking barefoot & (Antinori et al. 1992) \\
\hline 25. 27 & M & + & $\mathbf{R}$ & Close contact with horses & (Drancourt et al. 1992) \\
\hline 26. 22 & M & + & $\mathrm{D}$ & Worked on a farm & (Gray 1992) \\
\hline 27. 35 & M & - & $\mathbf{R}$ & Visited a sheep farm...had a source of exposure to dome & $\begin{array}{l}\text { stic horses } \\
\text { (Sladek \& Frame 1993) }\end{array}$ \\
\hline 28. 3 & $\mathrm{~F}$ & - & $\mathbf{R}$ & Dog (striking similarities to the ref. No 2) & (Verville et al. 1994) \\
\hline 29. 18 & $\mathbf{M}$ & + & D & Exposure to horses & (Verville et al. 1994) \\
\hline 30. 53 & $\mathbf{M}$ & - & $\mathbf{R}$ & Exposure to livestock & (Verville et al. 1994) \\
\hline 31. 31 & M & + & $\mathrm{D}$ & Exposure to horses & (Verville et al. 1994) \\
\hline 32. 83 & $\mathrm{~F}$ & - & D & Strict vegetarian & (Walsh \& Cunha 1994) \\
\hline 33. 65 & M & - & $\mathbf{R}$ & An avid gardener ... used horse manure as fertilizer & (Adal et al. 1995) \\
\hline 34. 76 & $\mathrm{~F}$ & - & $\mathbf{R}$ & Horse breeder & (Bouchou et al. 1995) \\
\hline 35. 60 & $\mathbf{M}$ & - & $\mathrm{D}$ & Owned two ponies & (Stolk-Engelaar 1995) \\
\hline
\end{tabular}

Legend: $\mathrm{M}=$ male; $\mathrm{F}$ = female; + = HIV infected; - = HIV non-infected; $\mathrm{R}=$ recovered; $\mathrm{D}=$ died

The analysed group of 59 patients included 45 males ( $76 \%$ ) and 14 females, the male to female ratio (M:F) being 3.21. In the positive animal exposure group there were 27 males (77\%, M:F 3.38), in the negative animal exposure group 18 males (75\%, M:F 3.0; $\mathrm{p}>0.05$ ).

The age of the persons with the positive animal exposure ranged from 1 to 83 years with the median of 30 years and the mean of 36.0 years, the age of individuals without the animal contact ranged from 3 to 66 years with the median of 39 years and the mean of 36.8 years $(\mathrm{p}>0.05)$.

HIV infection was present in 28 persons altogether, viz. in 16 out of 35 with the positive animal exposure (46\%) and in 12 out of 24 without it $(50 \%$; $>0.05)$.

The clinical outcome was fatal in 21 cases, in 10 out of $35(29 \%)$ with the positive animal exposure and in 11 out of $24(46 \%)$ without it. The difference was not statistically significant ( $p>0.05$ ). The summary of results is given in Table 2 .

Table 2

Summary of results concerning age, sex, HIV infection status and clinical outcome in $R$. equi infected patients with and without a contact with animals

\begin{tabular}{|l|c|c|c|c|c|}
\hline $\begin{array}{l}\text { Animal and/or } \\
\text { soil exposure }\end{array}$ & $\begin{array}{c}\text { Mean } \\
\text { age } \\
\text { (years) }\end{array}$ & $\begin{array}{c}\text { Median } \\
\text { age } \\
\text { (years) }\end{array}$ & $\begin{array}{c}\text { Male to } \\
\text { female ratio }\end{array}$ & $\begin{array}{c}\text { HIV+ } \\
(\%)\end{array}$ & $\begin{array}{c}\text { Lethality } \\
(\%)\end{array}$ \\
\hline positive $(\mathrm{n}=35)$ & 36.0 & 30 & 3.38 & 46 & 29 \\
negative $(\mathrm{n}=24)$ & 36.75 & 39 & 3.00 & 50 & 46 \\
\hline
\end{tabular}

\section{Discussion}

$R$. equi strains were isolated from soil from sites with variable land uses. They were found in faeces and dung pats of cattle, horses, sheep, pigs and goats but it seems that 
their presence in the gut of herbivores is transient and depends upon ingestion of pasture or feedstuffs contaminated with this organism. Being an aerobe, little or no multiplication of $R$. equi occurs in the gut, voided dung providing a more favourable environment for its multiplication outside the animal host (B arton and Hughes 1984, Prescott 1991).

Hughes and Sulaiman (1987) reported that $R$. equi grew substantially better in soils enriched with faeces than in soils alone. Simple organic acids in horse dung, especially acetate and propionate, appear to support growth of $R$. equi in the environment.

$R$. equi have been isolated also from the manure of a high proportion of wild birds but it is uncommonly present in the manure of chicken. The organism appears rare in the faeces of dogs and so far has not been isolated from cats (Prescott 1991).

Thus, exposure to soil contaminated with herbivore manure is likely the major route of both animal and human infection. Contact with farm animals, manure or soil was reported in 35 (30\%) of all cases of R. equi infection in man and denied in 24 cases (21\%). Considering that this epidemiologic information was missing in 56 out of 115 reports (49\%), the true percentage may be even higher. The same conclusion was reached by Verville et al. (1994). The presentation of $R$. equi infections as pneumonia or as a disease associated with the gastrointestinal tract without pulmonary involvement suggests that humans and animals can acquire infection by either inhalation or ingestion of contaminated material. Human and animal infection can be also acquired by traumatic inoculation or superinfection of wounds (Verville at al. 1994).

In the first review of $R$. equi infection in patients with and without HIV infection Harvey and Sunstrum (1991) noted that a history of exposure to farm animals or manure was reported in 9 of the 20 cases in patients without HIV infection, such a history was reported for only two of $11 \mathrm{HIV}$ infected patients. The difference between the two groups of patients was probably accidental because the further reports on $R$. equi infection in HIV positive persons brought the difference almost to zero. Our analysis of 51 papers with either confirmed or denied exposure to animals or soil showed the positive contact in 16 of $23 \mathrm{HIV}$ infected cases ( $70 \%$ ) and in 20 of $28 \mathrm{HIV}$ negative cases $(71 \%)$.

An insignificant age difference was apparent, most of persons with the positive exposure to animals being somewhat younger. Their median age was 30 years in comparison with the median age of patients without the animal contact which was 39 years. Mean age was almost identical in both groups ( 36.0 versus 36.8 years; $p>0.05$ ).

The male:female ratio in the positive animal exposure group was almost the same as in the negative animal exposure group ( 3.38 in the former versus 3.0 in the latter). Generally, predominance of $R$. equi infection in males was partly explained by cases of HIV infected men, slight predominance of $R$. equi infection in males with the positive animal exposure was probably given by the difference in men's occupation. No author has yet noted the differences in age and male:female ratio mentioned above.

In the animal exposure negative group the fatal clinical outcome was higher, there were reported in 24 cases $(46 \%)$ with denied animal contact whereas in 35 patients with the positive animal contact the clinical outcome was fatal in 10 cases (29\%). Nevertheless, the difference was not statistically significant.

It is a pity that about one half of 115 reports on $R$. equi infection in man did not mention the possible exposure to animals, manure or soil. The contact was noted in 35 cases (30\%) and denied in 24 cases ( $21 \%$ ). It is probable that with a more thorough history of individual cases the true percentage may be higher. 


\section{Infekce vyvolané druhem Rhodococcus equi u člověka se zřetelem na možný kontakt infikovaných osob se zviŕaty}

Analýza 115 zpráv popisujících infekci druhem $R$. equi u člověka ukázala, že pouze 59 z nich (51\%) obsahovalo údaje o případné expozici vủči zvířatům, hnoji nebo pủdě. Pozitivní kontakt byl zaznamenán v 35 případech $(31 \%)$ a popřen ve 24 připadech $(21 \%)$. Nejběžnějšim typem kontaktu byla expozice vůči koním nebo koňskému hnoji, zmínka o ní se vyskytla v 18 případech. Dalším nejčastějším typem expozice byla práce v zemědělství. Ve skupině exponovaných vůči zvířatům byl střední věk 31 let, poměr muži:ženy 3,38 a fatální vyústění choroby v 10 případech z 35 (26\%). Ve skupině pacientů bez expozice vůči zvířatům byl střední věk 39 let, poměr muži:ženy 3,0 a k úmrtí došlo v 11 př́ipadech z 24 (46 \%). Tyto rozdíly nebyly významné. Co se týká přítomnosti infekce HIV, rovněž nebyl rozdíl mezi nemocnými s expozicí vůči zvíratům a bez ní; infekce HIV byla popsána u 16 z 35 pacientů exponovaných vůči zviŕatům r. u 12 z 24 pacientů neexponovaných. Lze uzavřít, že podrobnější epidemiologická anamnéza by pravděpodobně odhalila daleko vyšši procento osob infikovaných $R$. equi s pozitivní historii kontaktu se zvíraty.

\section{Acknowledgement}

The study was supported by grant No 3714-3 from the Internal Grant Agency of the Ministry of Health of the Czech Republic.

\section{References}

ADAL, K.A., SHINER, P.T., FRANCIS, J.B. 1995: Primary subcutaneous abscess caused by Rhodococcus equi. Ann. Int. Med. 122:317

ALLEN, U.D., NIEC, A., KEREM, E., GREENBERG, M., GOLD, R. 1989: Rhodococcus equi pneumonia in a child with leukemia. Pediatr. Infect. Dis. 8:656-658

ANTINORI, S., ESPOSITO, R., CERNUSCHI, M., GALLI, M., GALIMBERTI, L., TOCALLI, L., MORONI, M. 1992: Disseminated Rhodococcus equi infection initially presenting as foot mycetoma in an HIV+ patient. AIDS 6:740-742

BARTON, M.D., HUGHES, K.L. 1984: Ecology of Rhodococcus equi. Vet. Microbiol. 9:65-76

BERG, R., CHMEL, H., MAYO, J., ARMSTRONG, D. 1977: Corynebacterium equi infection complicating neoplastic disease. Am. J. Clin. Pathol. 68:73-77

BOUChOU, K., CATHÉBRAS, P., DUMOllard, J.M., POUlaRd, G., MiCHEL, V., SEGUIN, P., ROUSSET, H. 1999: Chronic osteitis due to Rhodococcus equi in an immunocompetent patient. Clin. Infect. Dis. 20:718-720

DOIG, C., GILL, M.J., CHURCH, D.L. 1991: Rhodococcus equi - an easily missed opportunistic pathogen. Scand. J. Infect. Dis. 23:1-6

DRANCOURT, M., BONNET, E., GALLAIS, H., PELOUX, Y., RAOULT, D. 1992: Rhodococcus equi infection in patients with AIDS. J. Infect. 24:123-131

EBERSOLE, L.L., PATURZO, J.L., 1988: Endophthalmitis caused by Rhodococcus equi Prescott serotype 4. J. Clin. Micro- biol. 26:1221-1222

EGAWA, T., HARA, H., KAWASE, I., MASUNO, T., ASARI, S., SAKURAI, M., KISHIMOTO, S. 1990: Human pulmonary infection with Corynebacterium equi. Eur. Respir. J. 3:240-242

EMMONS, W., REICHWEIN, B., WINSLOW, D.L. 1991: Rhodococcus equi infection in the patient with AIDS: Literature review and report of an unusual case. Rev. Infect. Dis. 13:91-96

FLEPP, M., LUTHY, R., WUST, J., STEINKE, W., GREMINGER, P. 1989: Rhodococcus equi-Infektionen bei HIV-Krankheit. Schweiz. Med. Wchschr. 119:566-574

GOLUB, B., FALK, G., SPINK, W.W. 1967: Lung abscess due to Corynebacterium equi. Report of first human infection. Ann. Intern. Med. 66:1174-1177

GRAY, B.M. 1992: Case report: Rhodococcus equi pneumonia in a patient infected by the human immunodeficiency virus. Am. J. Med. Sci. 303:180-183

HARVEY, R.L., SUNSTRUM, J.C. 1991: Rhodococcus equi infection in patients with and without human immunodeficiency virus infection. Rev. Infect. Dis. 13:139-145 
HUGHES, K.L., SULAIMAN, I. 1987: The ecology of Rhodococcus equi and physicochemical influences on growth. Veter. Microbiol. 14:241-250

KWON, K.Y., COLBY, T.V. 1994: Rhodococcus equi pneumonia and pulmonary malakoplakia in AIDS. Arch. Pathol. Lab. Med. 118:744-748

LASKY, J.A., PULKINGHAM, N., POWERS, M.A., DURACK, D.T. 1991: Rhodococcus equi causing human pulmonary infection: Review of 29 cases. South. Med. J. 84:1217-1220

MACGREGOR, J.H., SAMUELSON, W.M., SANE, D.C., GODWIN, J.D. 1986: Opportunistic lung infection caused by Rhodococcus (Corynebacterium) equi. Radiology 160:83-84

MARSH, J.C., VON GRAEVENITZ, A. 1973: Recurrent Corynebacterium equi infection with lymphoma. Cancer 32:147-149

MCNEIL, M.M., BROWN, J.M. 1994: The medically important aerobic actinomycetes: Epidemiology and microbiology. Clin. Microbiol. Rev. 7:357-417

OBANA, W.G., SCANNELL, K.A., JACOBS, R., GRECO, C., ROSENBLUM, M.L. 1991: A case of Rhodococcus equi brain abscess. Surg. Neurol. 35:321-324

PRESCOTT, J.F. 1991: Rhodococcus equi: An animal and human pathogen. Clin. Microbiol. Rev. 4:20-34

ROUQUET, R.M., CLAVE, D., MASSIP, P., MOATTI, N., LEOPHONTE, P. 1991: Imipenem/vancomycin for Rhodococ - us equi pulmonary infection in HIV-positive patient. Lancet 337:375

SAMIES, J.H., HATHAWAY, B.N., ECHOLS, R.M., VEAZEY, R.M., PILON, V.A. 1986: Lung abscess due to Corynebacterium equi. Report of the first case in a patient with acquired immune deficiency syndrome. Am. J. Med. 80:6\&.5-688

SCOTT, M.A., GRAHAM, B.S., VERRALL, R., DIXON, R., SCHAFFNER, W., THAM, K.T. 1995: Rhodococcus equi - An increasingly recognized opportunistic pathogen. Report of 12 cases and review of 65 cases in the literature. Clin. Microbiol. Infect. Dis. 103:649-655

SLADEK, G.G., FRAME, J. N. 1993: Rhodococcus equi causing bacteremia in an adult with acute leukemia. South. Med. J. 86:244-246

STOLK-ENGELAAR, M.V., DOMPELING, E.C., MEIS, J.F.G.M., HOOGKAMP-KORSTANJE, J.A.A. 1995: Disseminated abscesses caused by Rhodococcus equi in a patient with chronic lymphocytic leukemia. Clin. Infect. Dis. 20:478-479

VANETTA, L.L., FILICE, G.A., FERGUSON, R.M., GERDING, D.N. 1983: Corynebacterium equi: A review of 12 cases of human infection. Rev. Infect. Dis. 5:1012-1018

VER VILLE, T.D., HUYCKE, M.M., GREENSFIELD, R.A., FINE, D.P., KUHLS, T.L., SLATER, L.N. 1994: Rhodococcus equi infections of humans. 12 cases and a review of the literature. Medicine 73:119-132

VESTBO, K., LUNDGREN, J.D., GAUB, J., ROEDER, R., GUTCHIK, E. 1991: Severe Rhodococcus equi pneumonia: Case report and literature review. Eur. J. Clin. Microbiol. Infect. Dis. 10:762-768

WALSH, R.D., CUNHA, B.A. 1994: Rhodococcus equi: Fatal pneumonia in a patient without AIDS. Heart and Lung 23:519-520

WANG, H.H., TOLLERUD, D., DANAR, D., HANFF, P., GOTTESDIENER, K., ROSEN, S. 1986: Another Whipple-like disease in AIDS? New Engl. J. Med. 314:1577-1578

Address for correspondence:

Doc. MUDr. M. Votava, CSc.

Department of Microbiology

Masaryk University, Medical Faculty

Pekařská 53

CZ-65691 Brno

Czech Republic 